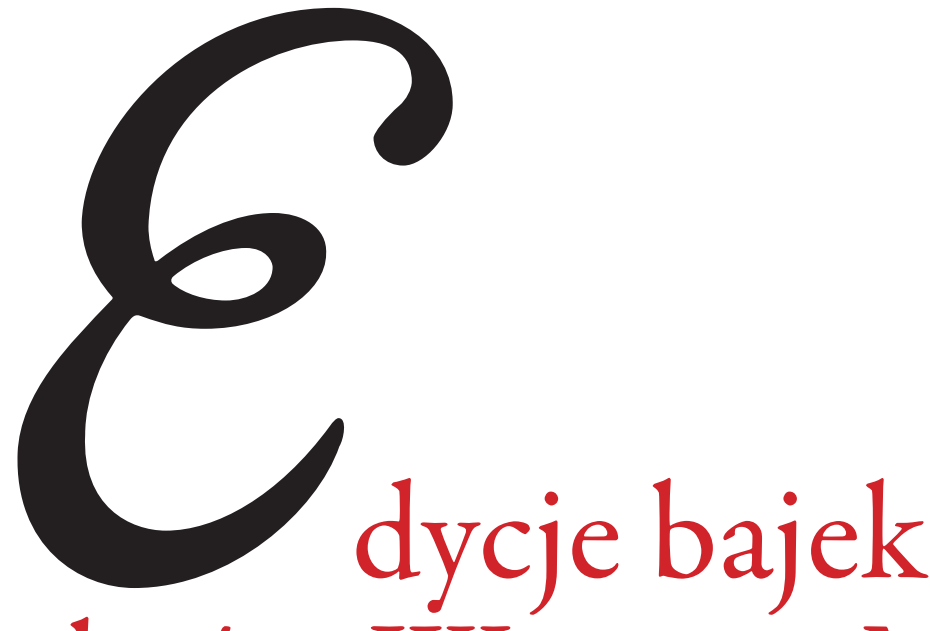
i baśni Warmii i Mazur (przegląd oraz tendencje)

Powojenna literatura dla dzieci i młodzieży na Warmii i Mazurach należy do wartościowych i niekwestionowanych osiągnięć literatury regionalnej. Utwory dziecięco-młodzieżowe, wydawane do początku lat dwutysięcznych, usystematyzowała i sproblematyzowała Teresa Brzeska-Smerek ${ }^{1}$, postulując badania nad nimi oraz przedsięwzięcia edytorskie:

Olsztyńskie i całe warmińsko-mazurskie środowisko literackie wpisało się trwale do dzisiejszego kanonu literatury dla dzieci i młodzieży, głównie baśniami i cyklem Zbigniewa Nienackiego [o Panu Samochodziku - Z. Ch.]. Jest jednak jeszcze kilku innych autorów, i przynajmniej kilka książek, które mogłyby zająć równie ważne miejsce w lekturach dzieci i młodzieży, gdyby doczekały się innych, ciekawszych edycji i większego niż dotychczas zainteresowania krytyki literackiej i instytucji zajmujących się upowszechnianiem literatury.

Potrzebne są zatem i reedycje, i szeroka praca upowszechniająca powstałą na Warmii i Mazurach literaturę intencjonalnie przeznaczoną dla małych i młodych odbiorców, jak i tę część spuścizny ludowej literatury regionu, która została przez dzieci i młodzież przyjęta. To bowiem literatura dawna i dzisiejsza z Warmii i Mazur wprowadziła do szerokiej świadomości walory krajobrazowe i wartości kulturowe regionu, służąc skuteczniej niż jakiekolwiek inne działania polityczne czy kulturalne procesom integracyjnym. Szczególną rolę w owym procesie odegrały baśnie, tak ludowe, jak i literackie².

Sztuka Edycji 2/2020 ISSN 2084-7963 (print) ISSN 2391-7903 (online) s. $79-88$

Gdy Brzeska-Smerek projektowała cytowany kierunek refleksji i działań, Violetta Wróblewska opracowała problematykę regionalnej baśni literackiej Warmii i Mazur ${ }^{3}$, a następnie przedstawiła jej wykład encyklopedyczny w Stowniku 
polskiej bajki ludowej4. Mimo tych cennych, zachowujących aktualność omówień istnieje potrzeba przejrzenia dorobku baśnio- i bajkopisarstwa Warmii i Mazur pod względem tekstologiczno-edytorskim. Biorąc pod uwagę przedsięwzięcia wydawnicze ostatniego trzydziestolecia obejmujące baśnie i bajki, po 1989 roku zarysowały się dwie główne tendencje. Pierwsza polega na kontynuacji, uzupełnianiu, multiplikacji i upowszechnianiu zasobów literatury bajkowo-baśniowej wytworzonych we wcześniejszych okresach. Drugą definiuje ujawnienie się nowych autorów, proponujących własne tematy i gatunki, formuły wydawnicze, wynikające z wolności tworzenia i publikowania; niebagatelne jest i to, że pisanie bajek i baśni zostało powiązane ze strategiami aktywizacji społeczności lokalnej, z kształtowaniem tożsamości regionalnej opartej już nie tylko na polonocentryzmie, a także z bardziej lub mniej doraźnymi akcjami edukacyjnymi. Dodajmy też, że zarówno uwarunkowania rynkowe, jak i dominacja kultury masowej również przyczyniły się do kształtowania poziomu i treści utworów, czego wyrazem jest ich symplifikacja czy podporządkowanie modnym lub po prostu aktualnym ideologiom społecznym. Oczywiście te dwie ledwo zarysowane tendencje niekiedy się przecinają.

Dokonując przeglądu wydawnictw bajkowo-baśniowych ostatniego trzydziestolecia związanych genezą z kulturą i historią Warmii i Mazur (dawnej południowej części Prus Wschodnich), widzimy pewne tendencje polegające na utrwalaniu, scalaniu, porządkowaniu i uzupełnianiu dwudziestowiecznych osiągnięć w tej dziedzinie. Szczególnie w dwóch pierwszych dekadach XXI stulecia pojawiły się nowe inicjatywy wydawnicze.

Zbiory baśni i bajek tylko niektórych powojennych twórców warmińsko-mazurskiego kanonu baśniowego i bajkowego ${ }^{5}$, do których należy Maria Zientara-Malewska, Karol Małłek, Klemens Oleksik, Tadeusz Stępowski, Maryna Okęcka-Bromkowa, Irena Kwintowa, zostały wznowione lub ukazały się w nowej formule edytorskiej. Umocniła się natomiast - przynajmniej lokalnie - pozycja zamieszkałej po 1945 roku w Kutach (między Giżyckiem i Węgorzewem) Jadwigi Tressenberg (podpisującej się też jako Stefańska-Tressenberg). Mimo że zadebiutowała w słynnym wieloautorskim Kiermaszu bajek z 1957 roku opowieścią Zemsta mieszkanki znad Żywego ${ }^{6}$, samodzielną pozycją książkową mogła się wykazać dopiero w 2000 roku. Wówczas wyszły jej Mazurskie opowieści składające się z dwudziestu czterech baśni; drugie ich wydanie, bogatsze o trzy nowe baśnie, ukazało się w Gołdapi w 2005 roku. Obie książki to typowe edycje lokalne, których każdy element (tekst, redakcja, ilustracje, opracowanie techniczne, korekta) jest uczyniony siłami miejscowego środowiska. Mazurskie opowieści są wydrukowane na papierze kredowym, co utrudnia czytanie. Wybór papieru kredowego nader często pomniejsza wartość edytorską publikacji.

We wstępie Jadwiga Tressenberg dziękuje wymienianym i niewymienianym z imienia i nazwiska ${ }^{8}$ mazurskim gawędziarzom, którzy mimo podeszłego wieku od końca lat czterdziestych XX stulecia opowiadali młodej wówczas, a przybyłej z Grodna nauczycielce stare lokalne przekazy o demonicznych postaciach i zdarzeniach, jakby ukrytych w okolicznym krajobrazie9. Gwarą mazurską po 1945 roku mówiło jeszcze głównie najstarsze pokolenie Mazurów.

Edycja książki Tressenberg symbolicznie dokumentuje zniknięcie - wraz z odejściem najstarszej generacji autochtonów - stosowanej przez etnografów zarówno przedwojennych (m.in. przez Emilię Sukertową-Biedrawinę), jak i powojennych metody tworzenia baśni. Utrwalił ją modelowo debiut książkowy Maryny Okęckiej-Bromkowej Nad jeziorem bajka śpi z 1962 roku $^{10}$ - tutaj każdy z baśniowych przekazów opatrzony jest imieniem i nazwiskiem ludowego gawędziarza-informatora, który dostarczył autorce-redaktorce pierwotną wersję, opracowaną później literacko przez znawczynię i zbieraczkę folkloru. Baśniowe i bajkowe, a zwłaszcza pieśniowe dziedzictwo Warmii i Mazur, istniejące tu od wieków w języku polskim, zostało uratowane przede wszystkim dzięki rozpoczętej w 1950 roku przez Państwowy Instytut Sztuki akcji (uczestniczyli w niej niektórzy współautorzy Kiermaszu bajek z 1957 roku, m.in. Alojzy Śliwa). Na skutek poszukiwania, notowania i nagrywania na taśmy magnetofonowe zachowanych na Powiślu, Warmii i Mazurach pozostałości polskojęzycznej kultury oralnej w ciągu kilku lat uratowano ponad sześć tysięcy warmińskich i mazurskich baśni, podań $i$ legend.

Okęcka-Bromkowa do 1981 roku pracowała w Radiu Olsztyn, nagrywając pieśni i opowieści regionalne. Na podstawie tego materiału ułożyła szereg swoich książek, z których najciekawsze, w interesującym nas kontekście, są gawędy myśliwskie pt. Z kolankiem i bez (Olsztyn 1965). Autorami ich pierwotnych wersji są mazurscy myśliwi.

Czytając baśnie innych warmińsko-mazurskich literatów, nie możemy zapominać, że ich talent pisarski polegał zasadniczo na umiejętności parafrazowania tekstów zasłyszanych od Warmiaków i Mazurów. Baśniopisarstwo regionalne rozwinęło się również dzięki zdobywaniu zaufania u autochtonów. Jedynie dla rodowitych mieszkańców, takich jak Maria Zientara-Malewska i Karol Małłek, baśnie były przekazami 


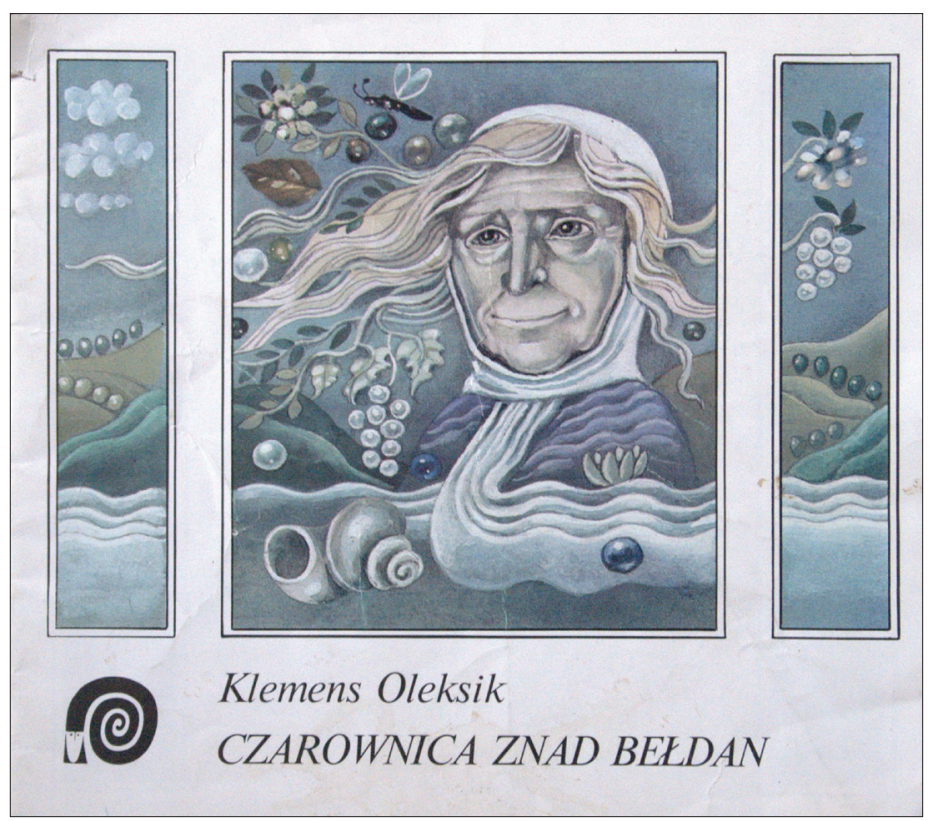

Il. 1. K. Oleksik, Czarownica znad Betdan, Warszawa 1989

rodzimymi, a nawet rodzinnymi. Nawiasem mówiąc, zastanawiające jest to, że autorzy, którzy przybyli z Wołynia (Okęcka-Bromkowa), Wileńszczyzny (Irena Kwinto), Grodzieńszczyzny (Jadwiga Tressenberg) lub innych regionów, nie zaszczepili w swoich utworach tradycji baśni i bajek stron rodzinnych, które opuścili.

Najobszerniejszy baśniowy zbiór Marii Zientary-Malewskiej ukazał się dopiero dwadzieścia cztery lata po jej śmierci, w 2008 roku, pt. O różnych ktobukach, skarbach i zaklętych zamkach (zob. il. 2) w wyborze i opracowaniu regionalisty, Jana Chłosty ${ }^{11}$. Redaktor połączył w jedną całość baśniowe narracje warmińskiej pisarki pochodzące z jej dwóch książek: Legendy dwóch rzek (1955) oraz Baśnie znad Eyny (1970, wyd. 2 - 1974), a także publikacji rozproszonych oraz wydobytych z rękopisów (na s. 8 i 9 zamieszczono reprodukcje dwóch kart zapisanych odręcznym pismem autorki). W Nocie wydawniczej nie zostały podane miejsca pierwodruków poszczególnych baśni. Czytamy w niej natomiast:

Redaktor opracowania nie dokonywał większych zmian w zamieszczonych tekstach. Zmieniona została tylko pisownia nazw geograficznych bądź nazw miejscowości i jezior, jak: Mosąg zamiast Mosęg, Kiernoz, a nie Kiernos, Bartąg zamiast Bartęg, Brąswałd zamiast Brązwałd, Berkweda zamiast Bergfreda, Pęglity zamiast Penglity, Sarąg zamiast Sarong, nadto warmiński, a nie warmijski, kiermas, a nie kiermasz.
Pragnąc uczynić tekst bardziej czytelnym, wydawca zamieścił w końcu książki słowniczek wyrażeń gwarowych, które autorka wprowadziła do baśni i legend ${ }^{12}$.

Zabieg dodawania słownikowych aneksów lub przypisów wyjaśniających w książkach z tekstami Mazurów i Warmiaków nie należał do rzadkości. Co oczywiste, im mniejszy stopień ingerencji w oryginalny przekaz gwarowy, tym więcej wymaga on dodatków wspierających jego rozumienie.

Utwory baśniowe Ireny Kwinty, która zadebiutowała w Nowym kiermaszu bajek (1962) aż pięcioma narracjami, ukazywały się w autorskich zbiorkach w latach 1976-1987 ${ }^{13}$. Jedenastoletni okres niewydawania jej książek przerwało powołanie w Lidzbarku Warmińskim rodzinnego Wydawnictwa WRZOS im. I. Kwinty założonego w 1998 roku przez syna pisarki, Stanisława Kwintę (występującego w roli redaktora), i wnuka, Michała Prewysza-Kwintę (składacza oraz ilustratora utworów swej babci) ${ }^{14}$. Oficyna opublikowała sześć tomików składających się zazwyczaj z kilku tekstów narracyjnych bogato ilustrowanych: Legendy o kwiatach (1998), Bajki

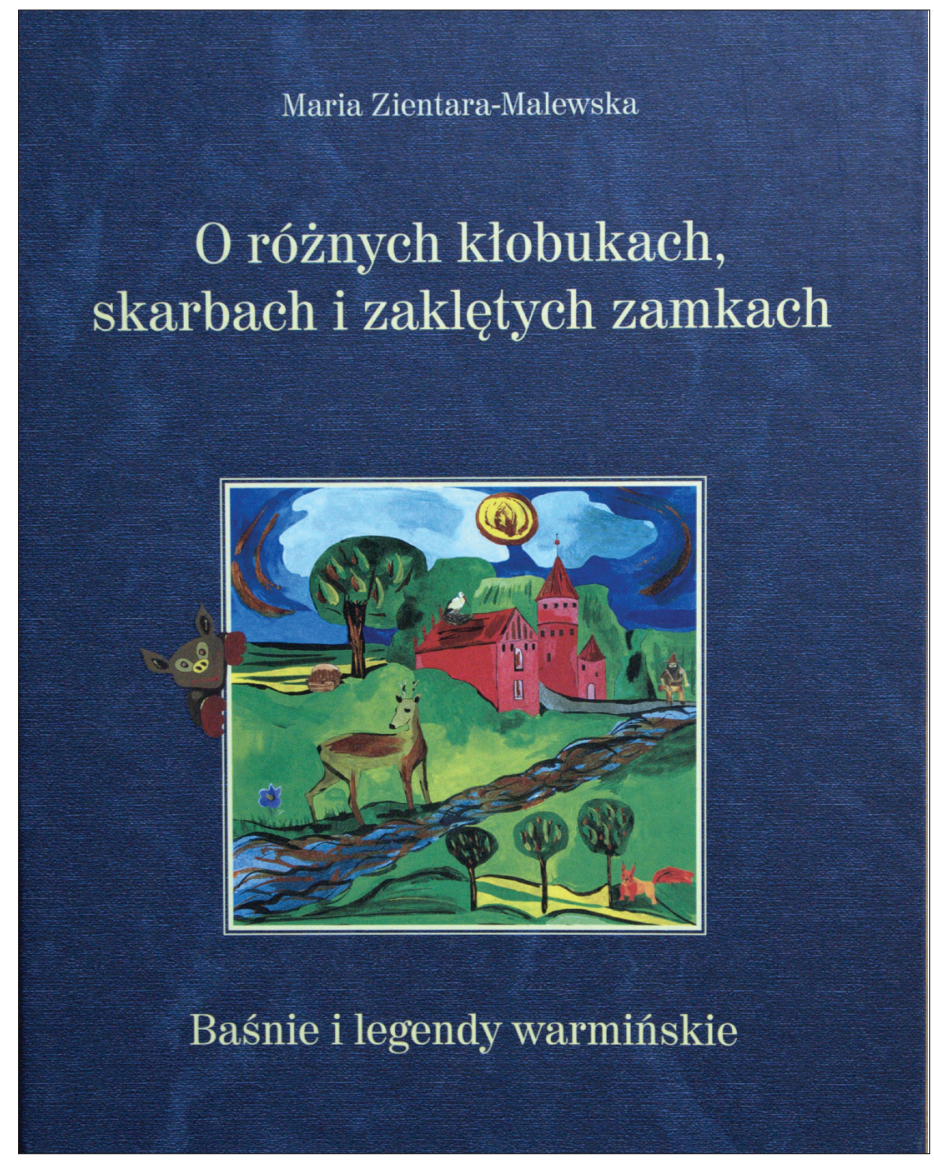

Il. 2. M. Zientara-Malewska, O różnych ktobukach, skarbach i zaklętych zamkach, wybór, oprac. i wstęp J. Chłosta, Olsztyn 2008 
sceniczne (1999), W krainie wielkiej baśni (2000), Legendy Warmii i Mazur (2001), Warmińskie legendy o Smętku i ktobukach (2002), Legendy Krainy Tysiaca Jezior (2004) - w tej ostatniej książeczce zamieszczono niedrukowaną dotychczas opowieść baśniową O kłobuku - takomczuchu (s. 37-48).

Pod względem typograficznym w edycjach zostały popełnione pewne błędy, np. tam, gdzie powinna być zastosowana półpauza, konsekwentnie występuje łącznik. Książki - zgodnie $\mathrm{z}$ intencją autorki - są adresowane do najmłodszego czytelnika, o czym świadczą m.in. odpowiednio duża czcionka czy ilustracje w poetyce filmów animowanych dla dzieci. Jak spostrzegła Anita Romulewicz, „grafiki Michała Prewysza-Kwinty mogą kusić dzieci łase na soczyste barwy niczym z filmów Disneya, to jednak ma się wrażenie, że bliżej im do japońskiej mangi niż do opowieści znad rodzimych jezior i lasów"15.

Warto zauważyć, że trzy zbiorki Kwinto: W krainie wielkiej baśni, Legendy Warmii i Mazur oraz Bajki Warmii i Mazur, zilustrowały dzieci, a tym samym spełniło się marzenie pisarki. Umieszczanie w książkach dla najmłodszego odbiorcy dziecięcych prac plastycznych uzyskało status zjawiska nowych czasów. Przypomnijmy, że łączenie tekstów dorosłych z obrazkami czy rysunkami dziecka we wcześniejszych dekadach nie było regułą, lecz ewenementem, jak w Wierszach i obrazkach (1970) Juliana Przybosia, które zawierają prace córki poety, Uty Przyboś. Anita Romulewicz pisała:

Swoistym novum w regionalnej sztuce edytorskiej stała się w latach 90-tych praktyka ilustrowania książek dla najmłodszych pracami wykonanymi przez dzieci. Tomik poetycki Maryny Okęckiej-Bromkowej z 1996 r. nosi nieco barokowy, ale wiele mówiący tytuł Deszczem wiatr podszyt sukmanę, a Maryna Okęcka-Bromkowa to podszywanie spisata! w latach 1958-1996. A dzieci-w wieku 7 do 12 lat ze szkoty $w$ Maltajnach ilustrowaty ${ }^{16}$. Trzy lata wcześniej, jako praca wspólna oraz „dzieło otwarte”, powstał zbiór opowiadań Dariusza Lisa Zwierzęta $z$ domu pod kasztanowcem - produkt wielkogabarytowy i interaktywny. Jak podkreślił edytor (olsztyńskie wydawnictwo Etos), książka była wyjątkowa już na etapie powstawania tekstu, w którego ostateczny kształt mogli ingerować sami czytelnicy. Autorem ilustracji został kilkuletni wówczas syn olsztyńskich plastyków - Kuba Obarek ${ }^{17}$.
Karola Małłka Opowieści znad Mazurskiego Gangesu (Warszawa 1964) nie doczekały się wznowienia po 1989 roku, choć należą do rodzimej tradycji historii uciesznych, komicznych, które w wielu niezbadanych wariantach ${ }^{18}$ przechodziły z pokolenia na pokolenie. Karol Małłek uosabiał typ międzywojennego etnografa-zbieracza. W jego mniemaniu oczywistością było to, że krążące ustnie narracje w społecznościach lokalnych trzeba spisać i opracować literacko. We wstępie do Opowieści znad Mazurskiego Gangesu stwierdzał:

Tutaj, nad pięknym Mazurskim Gangesem, zakotwiczyłem i ja końcowy etap mego życia i w moich krutyńskich zadumaniach zebrałem te opowieści, aby je utrwalić i przekazać czytelnikom z całej Polski. Są one częścią moich zbiorów folklorystycznych, oparte na motywach ludowych gadek mazurskich, które w ciągu sześćdziesięciu lat życia słyszałem od znanych gawędziarzy z powiatów działdowskich, nidzickiego, szczytnowskiego, mrągowskiego, 
z opublikowaniem Zauroczeń warto zauważyć, że nieco wcześniej, w drugiej połowie lat osiemdziesiątych, wydawców zainteresowały utwory baśniowe z motywami demonicznymi, czego znamiennym przykładem jest Baśń o Ktobuku psotniku Józefa J. Rojka (1986, wyd. 2 - 1987) czy wybór Bajki warmińsko-mazurskie o diabtach, ktobukach, smątkach $i$ kotbogach (1989; zob. il. 3) 21. W 1994 roku Towarzystwo Naukowe im. Wojciecha Kętrzyńskiego wydało demoniczne bajki mazurskie Emilii Sukertowej-Biedrawiny pt. Jak Konopka diabta wypedzat opracowane przez Tadeusza Orackiego ${ }^{22}$. Temu zasłużonemu edytorowi i badaczowi piśmiennictwa Warmii i Mazur zawdzięczamy najobszerniejszy zbiór maksymalnie zminiaturyzowanych i surowych pod względem literackim bajek Warmii i Mazur pt. Jak Mazurowi diabet matkę dat (Gdańsk 1995) 23. Zgodnie z powojenną tradycją regionalnego baśnio- i bajkopisarstwa edycja ma wyeksponowany

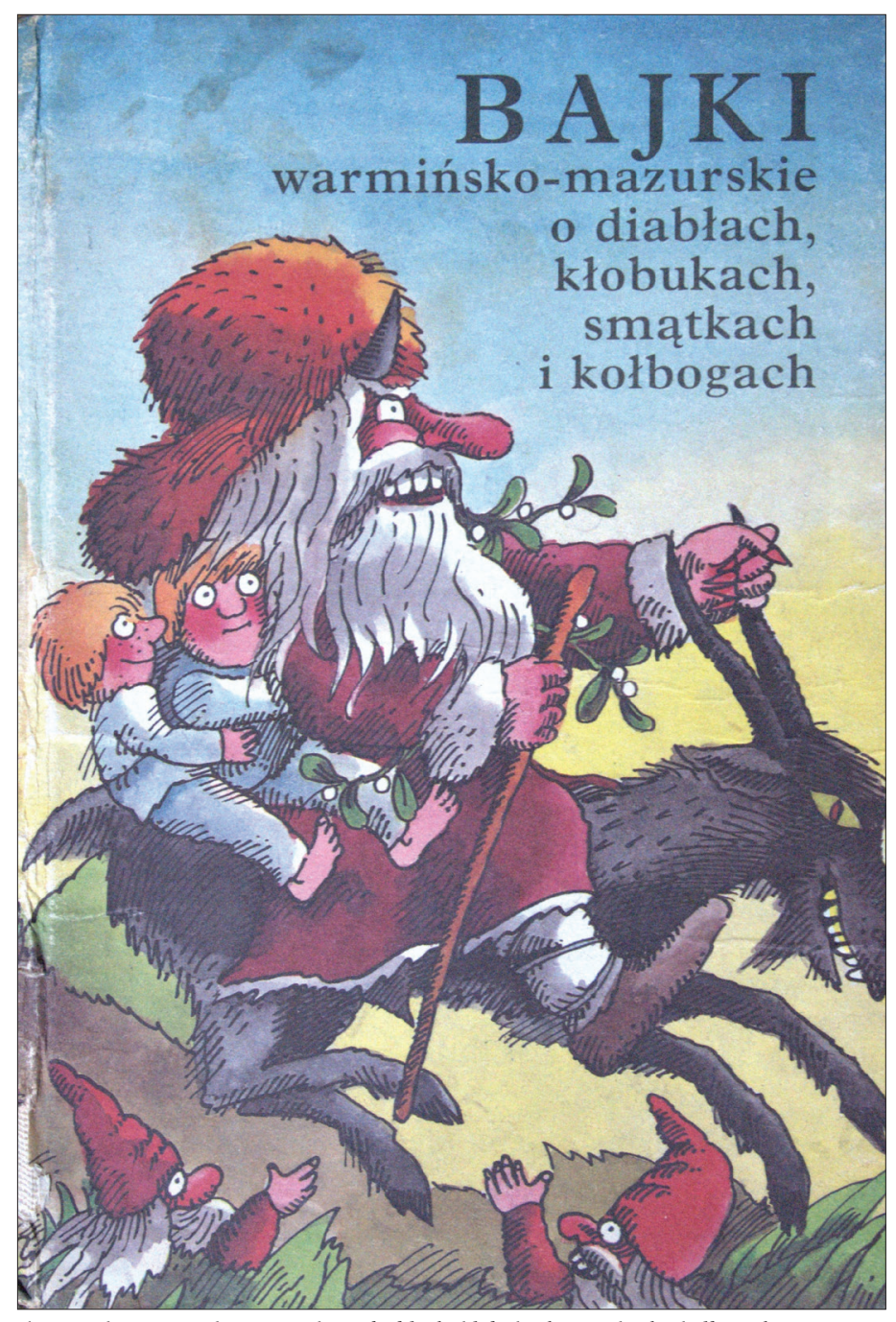

Il. 3. Bajki warmińsko-mazurskie o diabtach, ktobukach, smatkach $i$ kotbogach, pod red. B. Bartela, Warszawa 1989 polonocentryczny charakter. Jednak o wyjątkowości wydania decyduje systematyzacja bajek, a także dodanie do nich bibliografii przedmiotowej, obszernej noty edytorskiej oraz źródeł tekstów z komentarzami.

Ćwierć wieku po ukazaniu się tego tomu można stwierdzić, że zgromadzony w nim materiał oraz zawarte w nim ustalenia domagają się zarówno uzupełnień, jak i krytycznego oglądu. Dzieło Orackiego pozostaje nadal jedyną nowszą naukową, choć niepozbawioną wad edycją „,bajki Warmii i Mazur" (brak w niej np. głębszej refleksji nad ich genezą, językiem i semantyka).

Edycją założycielską historii wydawnictw baśni regionalnych jest tom Bajki Warmii i Mazur z 1956 roku; wydzielono w nim pod względem genologicznym cztery grupy utworów: Bajki zwierzęce, Baśnie, opowiadania i legendy, Opowiadania anegdotyczne, Bajki podaniowe. Jedyny to przykład genologicznej pieczołowitości w edycjach tego typu, odnoszących się do bajkopisarstwa i baśniopisarstwa Warmii i Mazur. Halina Koneczna i Wanda Pomianowska zamieściły Kilka uwag o fonetyce gwar Warmii i Mazur, Halina Kurowska opracowała objaśnienie znaków oraz trudniejszych wyrazów i zwrotów, a całość poprzedził Przedmowa Julian Krzyżanowski. Staranność edytorską zagwarantowało Polskie Wydawnictwo Naukowe ${ }^{24}$.

Wzorcowym i udanym powojennym przedsięwzięciem popularnych zbiorowych edycji baśni regionu były sygnowane przez Spółdzielnię Wydawniczą „Czytelnik”: Kiermasz bajek $(1957)^{25}$ i Nowy kiermasz bajek (1962; zob. il. 4) ${ }^{26}$; oba zbiory są komplementarne, a żaden z tekstów z pierwszego tomu nie jest powtórzony w drugim tomie. Próbą nie tyle twórczego podtrzymania tej edytorskiej tradycji, ile powtórzenia sukcesu wydawniczo-ekonomicznego były zredagowane przez Józefa J. Rojka książki: Królowa jezior. Baśnie i legendy Warmii i Mazur (1988) ${ }^{27}$ oraz Baśnie z Krainy Tysiaca Jezior (1989) ${ }^{28}$. Toteż najwybitniejsza na Warmii i Mazurach znawczyni literatury dla dzieci i młodzieży, Teresa Brzeska-Smerkowa, uznała te zbiory za „pirackie niemal, bo przedrukowujące teksty z Kiermaszu bajek czy Nowego kiermaszu... bez podania źródła i sprowadzające autorów do roli informatorów, ludowych opowiadaczy" 29 .

Za powrót do wyjściowych, zaistniałych w drugiej połowie lat pięćdziesiątych ubiegłego wieku pisarsko-edytorskich praktyk należy uznać wydaną w 2011 roku Antologie Warminiska. Warmia w baśniach, podaniach i legendach w wyborze, opracowaniu i ze wstępem Brzeskiej-Smerkowej ${ }^{30}$. Antologistka skupiła się na warmińskiej części regionu, co jest wyjątkowe, gdyż w edycjach baśni i bajek zazwyczaj pomijano 


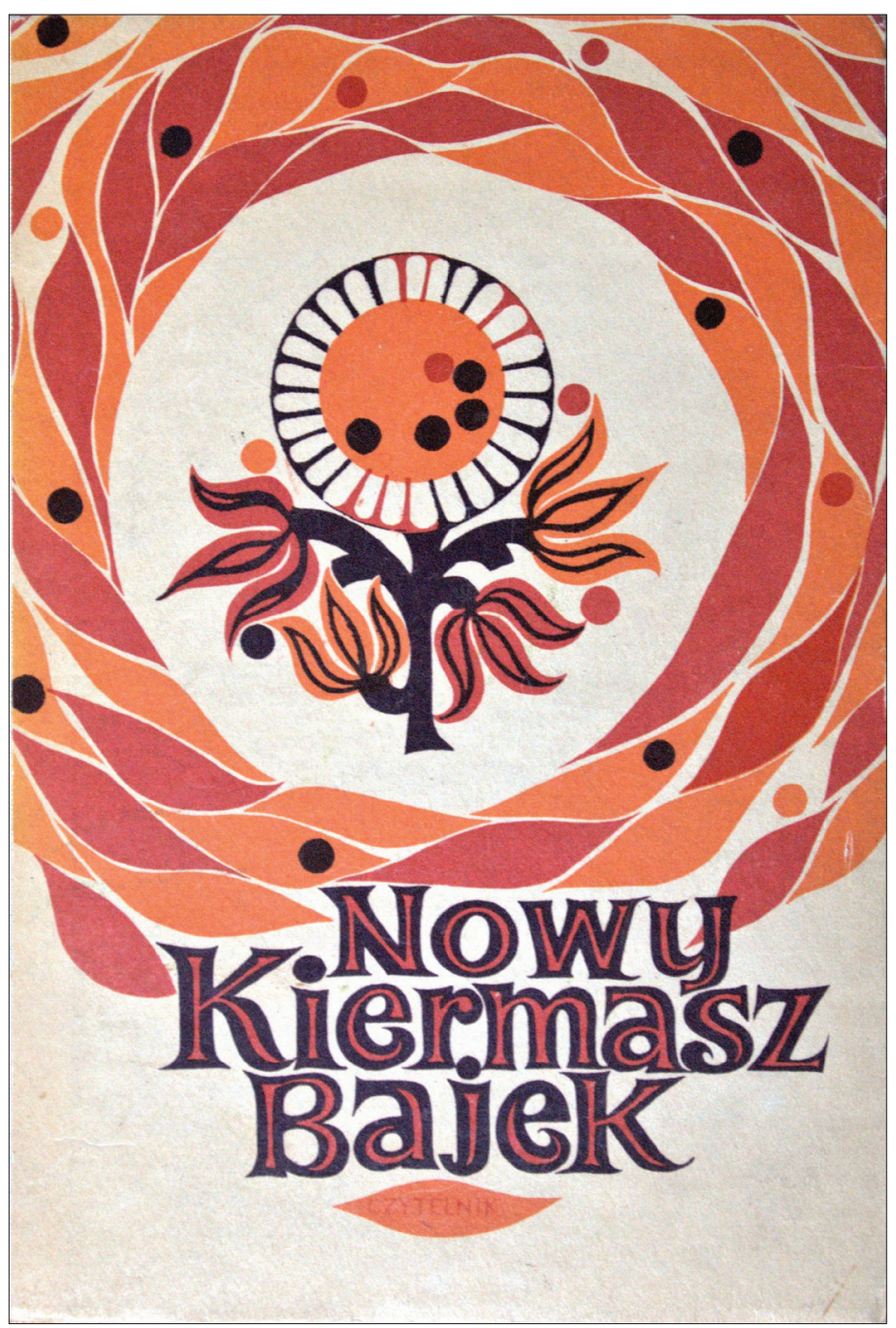

Il. 4. Nowy kiermasz bajek, wstęp W. Gębik, Warszawa 1962

jego dwudzielność i historyczną odmienność kulturową. Zbiór ten jest swego rodzaju warmińskim „nowym kiermaszem bajek", summą dwudziestowiecznego warmińskiego baśniopisarstwa. Redaktorka Antologii Warmińskiej przedrukowała z jednej strony takie baśnie, które koncentrują się na topografii Warmii (na rzece Łynie, jeziorach, morenowych wzgórzach, głazach narzutowych, miejscowościach, kulcie maryjnym), a z drugiej takie, których autorzy szczególnie interesowali się tożsamością warmińską i utrwalali ją. Chodzi tu zwłaszcza o Warmiaków: Marię Zientarę-Malewską, Martę Hanowską-Sendrowską, Augusta Steffena, Michała Lengowskiego, Alojzego Śliwę, a także o twórców, którzy po 1945 roku biograficznie oraz intelektualnie związali się z Warmią: Franciszka Jankowskiego, Irenę Kwintową, Marynę Okęcką-Bromkową, Tadeusza Orackiego czy Zofię Zymler-Hansową. Antologia Warminiska (zob. il. 5) zawiera też geograficzno-leksykalno-bibliograficzne aneksy: Indeks nazw geograficznych wraz ze stylizowaną mapką Warmii, Podręczny stownik nazw gwarowych, Źródta tekstów. Elementem unowocześniającym edycję jest załączona do książki płyta CD z filmem animowanym na podstawie baśni Zientary-Malewskiej Zaklęty zamek w Lesie Olsztyńskim. Ponadto poszczególne utwory dostępne są online i każdy z nich można pobrać w postaci pliku $\mathrm{PDF}^{31}$. Interesujące jest to, że powyższe przedsięwzięcie edytorskie powstało nie w celu umacniania polskości subregionu (który został w 1772 roku oderwany od Rzeczypospolitej i wszedł w skład terytorium Prus, a powrócił do Polski w 1945 roku), lecz kształtowania więzi współczesnych mieszkańców Warmii z Europą i jej dziedzictwem ${ }^{32}$. W jakimś sensie został ponownie przełamany partykularyzm regionalnego baśniopisarstwa. W okresie powojennym było przedstawiane jako dowód polskości Warmii i Mazur. W latach sześćdziesiątych ubiegłego wieku Halina Skrobiszewska, mając na myśli Kiermasz bajek i Nowy kiermasz bajek, pisała o ich ogromnej roli w integrowaniu kultury Warmii i Mazur z kulturą ogólnonarodową 33 .

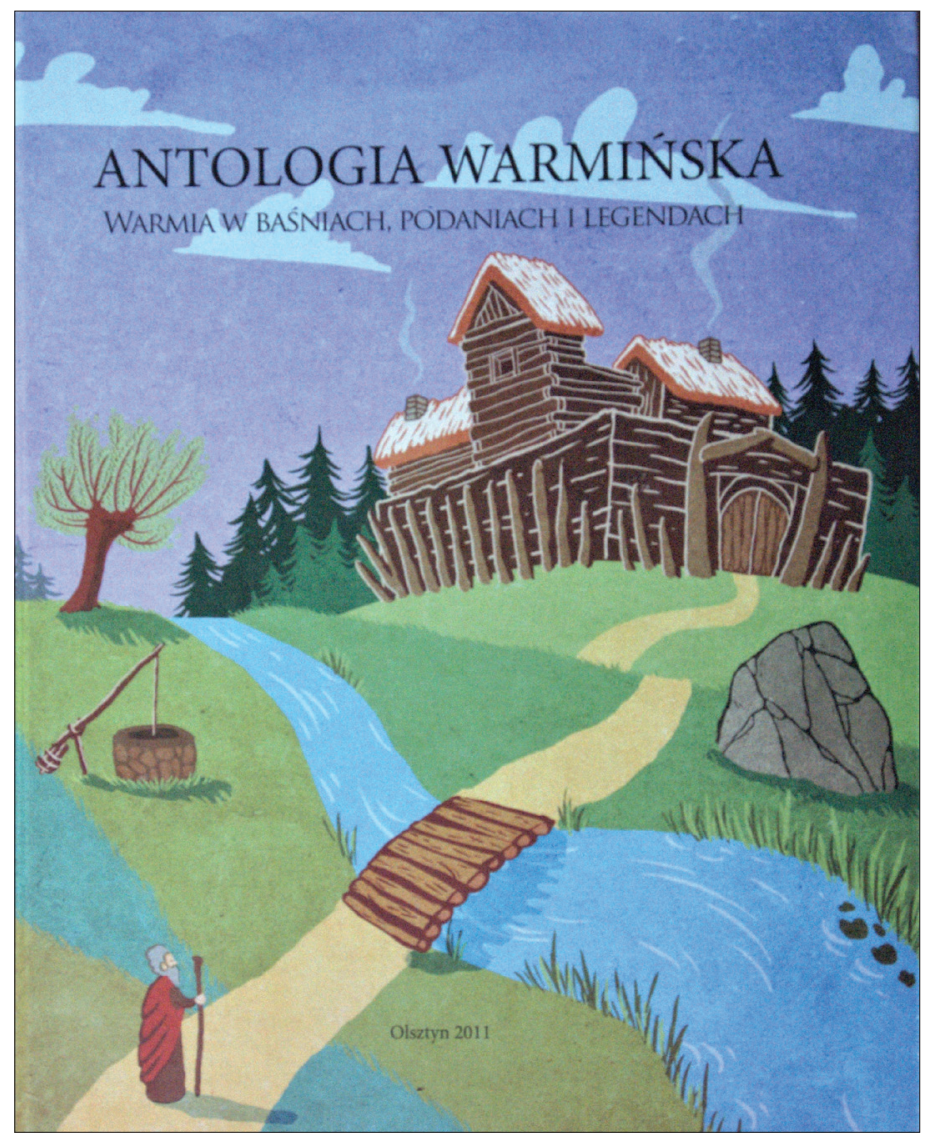

Il. 5. Antologia Warmińska. Warmia w baśniach, podaniach i legendach, wybór, oprac. i wstęp T. Brzeska-Smerek, Olsztyn 2011 
Osiem lat po Antologii Warmińskiej ukazała się niejako baśniowo-bajkowa antologia mazurska, co wynika wprost z profilu tematyczno-geograficznego działalności publikacyjnej jej wydawcy i współredaktora, właściciela Oficyny Wydawniczej Retman, Waldemara Mierzwy z Dąbrówna; przyznał on:

[...] konsekwentnie unikałem zakupów współczesnych „przeróbek” dawnych bajek regionalnych, których autorami byli nasi literaci. Za najważniejszą bajkową książę regionalną do dzisiaj uważam zbiór Bajki Warmii i Mazur wydany w 1956 roku przez PWN. Ten zbiór nie ma słabych punktów ${ }^{34}$.

Potwierdzeniem wierności temu sposobowi edytorskiego postępowania wobec źródeł są wydane przez Mierzwę w serii „Miniatury Mazurskie” bibliofilskie zbiorki; zapoczątkowała ją książeczka z 2011 roku Emilii Sukertowej-Biedrawiny pt. Diabet na Mazurach w baśniach i podaniach opracowana przez Jerzego Łapo - redaktor oparł edycję na ostatniej, datowanej na 1956 rok, wersji tekstu Sukertowej-Biedrawiny (jest on również autorem merytorycznego wstępu $O d$ djabta do diabta i zasad edycji ${ }^{35}$. Jeden z nich, opatrzony numerem 7, nosi tytuł Kierz róży. Bajki mazurskie z Dziatdowszczyzny, a opracowała go Ewa Sotomska (działdowska bibliotekarka i regionalistka) ${ }^{36}$, która przyjęła następujące zasady edycji:

Teksty bajek prezentowanych w zbiorze Kierz róży podano za „Gazetą Mazurską” i jej dodatkami: „Nasz Świat. Tygodnik dla naszej młodzieży” i „Nasz Światek. Miesięcznik dla naszej dziatwy", znajdujących się w zbiorach Książnicy Kopernikańskiej w Toruniu, oraz monografiami wsi opracowanymi przez kursantów Państwowego Seminarium Nauczycielskiego w Działdowie, które znajdują się w zbiorach Ośrodka Badań Naukowych w Olsztynie. Każdy tekst opatrzono informacją o źródle pochodzenia bajki.

Zmieniono dwa tytuły, które w oryginale nosiły nazwę Bajka mazurska, na $O$ synu, co zmartwień przysparzat oraz Pomocny kotek. Z tytułów innych usunięto słowa „Bajka o” i „Bajka mazurska o”.

Starano się ujednolicić pisownię, zachowując przy tym koloryt lokalny oraz słownictwo gwarowe, które objaśniono ${ }^{37}$.

Podobne zasady edycji zostały przyjęte w zbiorze bajek zwierzęcych pt. Zwierzyniec mazurski z 2016 roku $^{38}$.

\section{Wesele ptasząt}

Piosenka mazurska

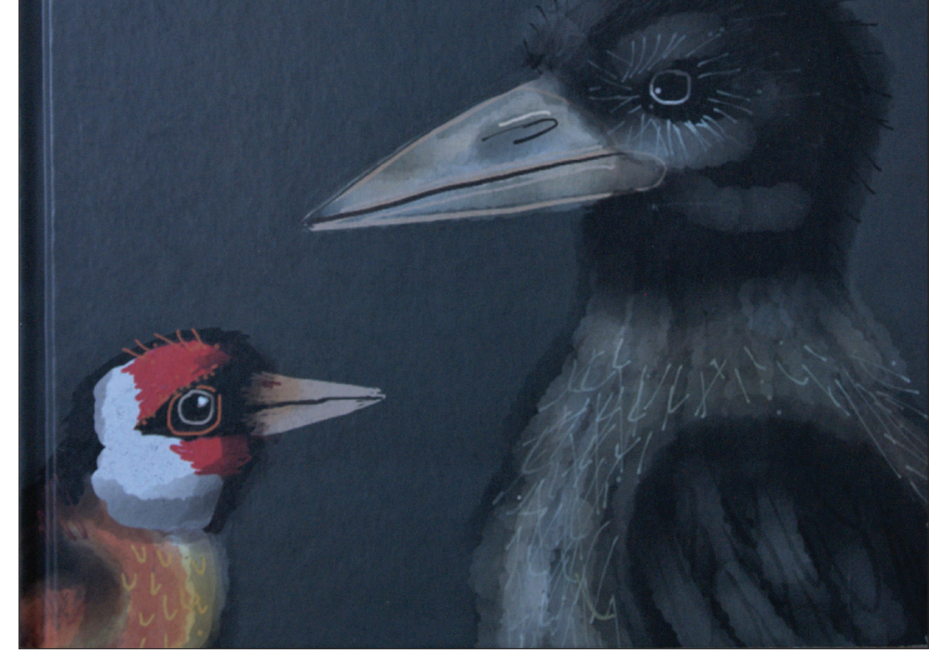

Il. 6. Wesele ptasząt. Piosenka mazurska, Olsztyn 2013

Wzmiankowane druki były zapowiedzią Bajek mazurskich, które ukazały się również w oficynie Waldemara Mierzwy wydającego od 2001 roku jedyną w swoim rodzaju serię „Moja Biblioteka Mazurska”. Opatrzone numerem 32 wyszły w niej właśnie Bajki mazurskie ${ }^{39}$ zawierające przedruki $\mathrm{z}$ wydawnictw periodycznych redagowanych przez Sukertową-Biedrawinę („Kalendarza dla Mazurów” i dziecięcego dodatku do „Gazety Mazurskiej” - „Nasz Światek”), a także z uwspółcześnionej polskiej edycji Maxa P. Toeppena Wierzeń mazurskich z 2008 roku $^{40}$, która pierwotnie ukazała się w przekładzie Eugenii Piltzówny jako odbitka z tomu szóstego „Wisły” w 1894 roku $^{41}$. Wydawca enigmatycznie zapewnia na tylnej okładce:

Niniejszy zbiór zawiera trzydzieści bajek, które ukazały się drukiem między 1867 a 1939 rokiem, przede wszystkim w kalendarzach i gazetach dla Mazurów. Zachowaliśmy ich oryginalne brzmienie, uwspółcześniając język jedynie w wyjątkowych przypadkach.

Na podstawie spisu treści, który zawiera adresy bibliograficzne pierwodruków, orientujemy się, że ich tytuły zostały zmienione, a także widnieje przy nich skrót „wg”, który sugeruje, że: Stokrotka powstała na podstawie Bajki mazurskiej o Stokrotce, O gtupim synu jest pochodną tekstu $O$ gtupim synie. Ucieszna bajka mazurska, podstawą Raka i indyka jest 
Bajka o madrym Raku z podtytułem Ucieszne opowiadania mazurskie, Skrzynia w nagrodę jest przetworzeniem Bajki mazurskiej (Pomocny kotek), zaś Chusteczka i pierścieńn narracji Jazda konno na czwarte piętro itd. Skrót „wg” jest niefortunny, gdyż informuje nie tyle o przeredagowaniu tytułu, ile całego tekstu danej bajki. W rzeczywistości jednak skrót „wg” pierwotnie zastosowała w pierwodrukach Sukertowa-Biedrawina, asekurując się przed zarzutami, że odstąpiła od oryginału, czyli będącego w jej posiadaniu przekazu. W opisach bibliograficznych dotyczących pierwodruków przejętych z Wierzeń mazurskich pojawienie się „wg” nie ma uzasadnienia. Teksty Bajek mazurskich brzmią stosunkowo współcześnie i uniwersalnie, więc zbędne było dodawanie przypisów czy układanie słowniczka gwarowego.

W pierwszych dekadach XXI wieku pojawiły się całkiem nowe zjawiska edytorskie w związku z baśniopisarstwem regionalnym. W okresie powojennym zatajano lub zacierano jego niemieckie źródła. Co prawda w 1983 roku Wydawnictwo „Pojezierze” opublikowało Baśnie Ernsta Wiecherta w przekładzie Tadeusza Ostojskiego ${ }^{42}$, ale wynikało to z nadzwyczajnego zainteresowania tym niemieckim pisarzem urodzonym na Mazurach ${ }^{43}$. Następnym krokiem w zbliżaniu czytelnika regionalnego do źródeł niemieckich było wydanie specjalne dwutygodnika „Warmia i Mazury” w formie książeczki pt. Bajki (oprawa miękka, ISBN-u brak) ${ }^{44}$ pod redakcją Tadeusza Willana (Mazura z Krutyni, dziennikarza i pisarza) ${ }^{45}$. Redaktor opracowywał baśnie Warmii i Mazur, niektóre ukazały się w Nowym kiermaszu bajek ${ }^{46}$. We wspomnianym wydaniu specjalnym obok przekładów utworów Ernsta Wiecherta, Jana Drdy, Marity Lindquist najwięcej znalazło się utworów klasycznych niemieckojęzycznych autorów bajek, zwłaszcza zwierzęcych: Karla Simrocka (Dar zwierzat), Ulricha Bonera (Lis i bocian, Lew i mysz, Wilk i bocian), Gerharda Mindena (Nietoperz), Johanesa Pauli (Lew i cztowiek), Heinricha Steinhöwela (Kot $i$ kogut, Gospodarz $i$ żmija) w tlumaczeniu Willana.

Odsłanianie niemieckich i niemieckojęzycznych tradycji bajko- i baśniopisarstwa Warmii i Mazur, a historycznie rzec biorąc - południowej części Prus Wschodnich, nastąpiło po 1989 roku. Przykładem tego zjawiska jest skromny zbiorek iławskiego literata, Wiesława Niesiobędzkiego, Księżniczka $z$ Kesselbergu $i$ inne legendy znad Jezioraka (2000). Autor bez ogródek przyznał się, że przy pisaniu każdej z dziesięciu legend korzystał z niemieckiej historii powiatu suskiego Alfreda
Müssego Der Kreis Rosenberg (1963) ${ }^{47}$ oraz zawartości „Heimat-Kurier” (Düsseldorf), organu prasowego ziomkostwa, zrzeszającego dawnych mieszkańców m.in. Deutsch-Eylau (niemiecka nazwa współczesnej Iławy). Legendy są wglądem w dzieje miejsc i ludzi iławskiej okolicy z prusko-niemieckiego punktu widzenia. Niesiobędzki uzasadniał swoją strategię narracyjną:

[...] gdy jednoczymy się z Europa, musimy bez uprzedzeń patrzeć na dzieje dawnych i obecnych mieszkańców naszego powiatu [iławskiego - Z. Ch.], których jednakowo doświadczył los, a historia tak jednych, jak i drugich nie składała się wyłącznie z wojen i nienawiśsici ${ }^{48}$.

Krzewienie nieuprzedzonego stosunku do dziedzictwa kulturowego Prus Wschodnich od 1990 roku było ideą Wspólnoty Kulturowej „Borussia”. W oficynie tego stowarzyszenia ukazały się dziesiątki ważnych pozycji literackich, historycznych, etnograficznych, które jej służyły. Jednym 
o bursztynowych wtosach. Mazurskie legendy i baśnie (1999); zawiera on niemieckie, opracowane na nowo, teksty wzięte z Wierzeń mazurskich Toeppena oraz ich polskie tłumaczenia. Za ilustracyjny materiał posłużyły grafiki Hieronima Skurpskiego $^{51}$.

Integralną częścią tej książki, oprawionej w płótno, są subtelne monochromatyczne ilustracje oraz opracowanie graficzne Zofii Góralczyk-Markuszewskiej, która przez całe dorosłe i twórcze życie związana była z Puszczą Piską. Na wklejkach Wielkiego skarbca... widnieją artystycznie wykonane przez ilustratorkę, nieco fantazyjne mapki obszaru, na którym rozgrywają się opisane zdarzenia. Trzeba zauważyć, że atrybutem wielu regionalnych publikacji stały się geograficzno-graficzne dodatki. Wielki skarbiec... zawiera też element nieoczekiwany w edycjach bajek czy legend. Jest nim część zatytułowana Ulubione potrawy Güntera Schiwy'ego. Stanowią ją przepisy kulinarne, które autor zapamiętał z dzieciństwa.

Dużą wartość badawczą ma „wielki zbiór podań ludowych z Mazur" pt. Czarci Ostrów, który zebrał z niemieckich źródeł etnograficznych, przełożył i opracował Jerzy M. Łapo ${ }^{52}$. Każde z podań jest opatrzone jego merytorycznym komentarzem.

Nie sposób tu wskazać wszystkich zjawisk występujących w edytorstwie baśni i bajek na Warmii i Mazurach. Zbieżne są one z tendencjami ogólnopolskimi. Na przykład łączą się z komiksem. Z cyklu „Legendy Warmińskie” powstały trzy komiksy na podstawie scenariusza Marcina Wakara i rysunków Jarosława Gacha: Jak chtop tabędzia za żonę wziąt (2006), O królu i chtopcu w czepku urodzonym (2008), Jak powstata wyspa Lalka na jeziorze Eańskim (2009) ${ }^{53}$. Ich postacie mówią polszczyzną literacką i gwarą warmińską (tę wersję językową opracował Warmiak i literat, Edward Cyfus). Jednym z celów tych publikacji była popularyzacja gwary warmińskiej, zresztą Cyfus wraz z Izabelą Lewandowską jest autorem Elementarza warmińskiego (2017). Analogiczne zjawisko nastąpiło, jeśli idzie o gwarę mazurską. Piotr Szatkowski (nazywający siebie Psiotrem ôt Sziatków) oddał w niej baśń Antoine’a de Saint-Exupéry'ego pt. Mati Princ (2018) ${ }^{54}$, a niedługo potem opracował Mazurski Fébel abo mazurská fibla, czyli elementarz mowy mazurskiej (2019) ${ }^{55}$.

Ujęte edycje baśnio- i bajkopisarstwa uwidaczniają zarówno żywotność oraz rozwój, jak i postępującą różnorodność ich formuł wydawniczych. Tendencja jest zrozumiała w dobie zwrotu do regionalizmu, definiowanego jako sposób budowania społeczeństw otwartych. Na uwagę zasługuje też to, że ambitnym autorom, redaktorom i wydawcom przyświeca pragnienie powrotu do źródeł baśni, bajek, legend, podań. Przegląd wydawnictw bajkowo-baśniowych Warmii i Mazur ostatniego trzydziestolecia ujawnia wybrane działania edytorskie, wznowienia regionalnych kanonicznych tytułów, ale także przypadki „piractwa”. Nowym sposobem postępowania autorów i wydawców stało się odsłanianie, zacieranych wcześniej (zwłaszcza w dekadach powojennych), niemieckich źródeł baśni Warmii i Mazur. Pojawiło się też zjawisko regionalizacji klasyki baśni.

Key Words: regional literature, local edition, regionalisation of fairy tales, German-Polish relations, reedition

Abstract: The article outlines textological and editorial issues related to the publication of original and collective fairy tales and fairy tales based on the ethnographic and historical sources of the region. Important and basic books in this field were recalled, which appeared in the period 1956-1989. Against this background, ambitious and valuable editions of fairy tales, as well as legends, stories, comic stories from the last thirty years were discussed. The described tendencies consist in the continuation, multiplication and renewal of $20^{\text {th }}$-century editing traditions of these literary genres. Their editions have been published: local, Polish-German, artistically marked, comics. They are included in broader - not always convergent - social strategies, such as: building ties with indigenous people, creating regional identity, strengthening the cultural heritage of Warmia and Mazury as part of Europe. Fairy tale editions play a role in the reactivation of the Warmian and Masurian dialects as well as the Prussian language.

'T. Brzeska-Smerek, Literatura Warmii i Mazur dla dzieci i młodzieży. Tradycja i wspótczesność, http://www.wbp.olsztyn.pl/bwm/3-4_04-ie/lit1.htm (dostęp: 5.04.2020). Jest to artykuł zamieszczony w internetowym wydaniu kwartalnika Wojewódzkiej Biblioteki w Olsztynie „Bibliotekarz Warmińsko-Mazurski” 2004, nr 3-4.

${ }^{2}$ lbidem.

${ }^{3}$ V. Wróblewska, Regionalna baśn literacka Warmii i Mazur, „Acta Universitatis Nicolai Copernici. Filologia Polska" 2002, t. 57, z. 354, s. 149-178.

${ }^{4}$ Zob. hasło Bajka ludowa na Warmii i Mazurach w internetowym wydaniu słownika pt. Polska bajka ludowa, https://bajka.umk.pl/slownik/lista-hasel/haslo/?id=269 (dostęp: 5.04.2020). Edycja książkowa: Stownik polskiej bajki ludowej, t. 1-3, pod red. V. Wróblewskiej, Toruń 2019.

${ }^{5}$ W ich kręgu znajdują się: Maria Zientara-Malewska (Legendy dwóch rzek z 1955 roku), Baśnie znad tyny z 1970 roku), Klemens Oleksik (Czarownica znad Bełdan z 1959 roku książka do 1989 roku miała pięć wydań; zob. il. 1), Tadeusz Stępowski (Czterej synowie Raka z 1959 roku), Karol Małtek (Opowieści znad mazurskiego Gangesu z 1964 roku), Irena Kwintowa (Dar królowej róż z 1971 roku, Pierścień orlicy z 1976 roku i Uśmiechnij się bajko z 1982 roku), a także Maryna Okęcka-Bromkowa ze zbiorem Nad jeziorem bajka śpi z 1962 roku.

${ }^{6}$ J. Stefańska-Tressenberg, Zemsta mieszkanki znad Żywego, w: Kiermasz bajek, wstęp i posłowie W. Gębik, Warszawa 1957, s. 235-244. W tym zbiorowym wydawnictwie znajdują się autorzy, którzy nie utrwalili się w pamięci społecznej jako pisarze bajek i baśni: Otylia Grotowa, Franciszek Jankowski, Zygmunt Kornowski, Michał Lengowski, Witold Piechocki, Teofil Ruczyński, Marta Sendrowska (z domu Hanowska), Alojzy Śliwa. Żadna z wymienionych osób nie ma w swoim dorobku autorskiego wydania baśni i bajek.

${ }^{7} \mathrm{~J}$. Tressenberg, Mazurskie opowieści, Pozezdrze 2000. 

nę Lallę.

${ }^{8}$ Chodzi o starych Mazurów i Mazurki: Gustawa Rydzewskiego, Ernesta Kullę, Hele-

${ }^{9}$ Na podstawie Mazurskich opowieści we wschodniej części Puszczy Boreckiej, w obrębie gminy Pozezdrze, powstała ścieżka rowerowa o nazwie „Szlak Legend Mazurskich”, którego punkty przystankowe są nazwane tytułami utworów zawartych w drugim wydaniu Mazurskich opowieści.

${ }^{10}$ M. Okęcka-Bromkowa, Nad jeziorem bajka śpi, wstęp i posłowie W. Cudowski, Olsztyn 1962 (wyd. 2 - 1979)

${ }^{11}$ M. Zientara-Malewska, O różnych kłobukach, skarbach i zaklętych zamkach, wybór, oprac. i wstęp J. Chłosta, Olsztyn 2008

12 [J. Chłosta], Nota wydawnicza, w: ibidem, s. 222

${ }^{13}$ Książki Kwinto sprzed 1989 roku: Pierścień orlicy, Olsztyn 1976 (wyd. 2 - 1987), Uśmiechnij się bajko (Olsztyn 1982, wyd. 2 - 1985), Dar królowej róż (Olsztyn 1985), Legenda o Łynie (Warszawa 1985) w popularnej i wysokonakładowej serii Krajowej Agencji Wydawniczej „Z krasnalem (Baśnie i Legendy z Całego Świata)”.

${ }^{14}$ Szczegółowa informacja na ten temat: http://www.kwinto.com/ksiazki.htm (dostęp: 16.04.2020).

${ }^{15}$ A. Romulewicz, Koronkowe ryby na niby, „VariArt” 2010, nr 3, s. 13. Jest to jedyny artykuł o ilustrowaniu książek warmińsko-mazurskich dla młodego czytelnika, które ukazały się po 1989 roku.

${ }^{16}$ Tomik nie zawiera stopki redakcyjnej i nie ma ISBN-u.

${ }^{17}$ A. Romulewicz, op. cit., s. 12

${ }^{18}$ Z. Chojnowski, Stylistyka i autorstwo (przekształcenia tekstowe w piśmiennictwie mazurskim XIX wieku), „Prace Językoznawcze” 2014, nr 3, s. 5-21. Mowa tu m.in. o wersjach mazurskiej historyjki o przygodzie Mazura, który złowił suma o ogromnych rozmiarach

${ }^{19}$ K. Małłek, Od autora, w: idem, Opowieści znad Mazurskiego Gangesu, Warszawa 1964, s. 5-6. Folklorystyczny zbiór bajek mazurskich Małtka jest przechowywany w archiwum Instytutu Północnego im. Wojciecha Kętrzyńskiego w Olsztynie.

${ }^{20}$ H. Skurpski, Zauroczenia, wstęp J. Chłosta, red. tekstów T. Baryła, Olsztyn 1994

${ }^{21}$ Bajki warmińsko-mazurskie o diabłach, kłobukach, smątkach i kołbogach, pod red. B. Bartela, Warszawa 1989. Zostały wykorzystane narracje wyjęte z Kiermaszu bajek oraz Nowego kiermaszu bajek Śliwy, Stępowskiego, Małtka, a także anonimowe. W książce nie podano źródeł przedruków.

${ }^{22}$ E. Sukertowa-Biedrawina, Jak Konopka diabła wypędzał. Bajki mazurskie, zebrał, oprac. i posł. T. Oracki, Olsztyn 1994

${ }^{23}$ T. Oracki, Jak Mazurowi diabeł matkę dał. Bajki Warmii i Mazur, Gdańsk 1995. Tytuł zbioru nawiązuje do przysłowia popularnego na Mazurach w XIX wieku, którego jeden z wariantów brzmi: „W Szestnie diabeł matke daje”; G. Optacy, W Szestnie diabeł matke daje, „Kalendarz Mazur i Warmii” 1958, s. 83-84.

${ }^{24}$ Bajki Warmii i Mazur, red. i wybór H. Koneczna, W. Pomianowska, przygotowanie do druku i przypisy H. Kurowska, przedmowa J. Krzyżanowski, Warszawa 1956.

${ }^{25}$ Kiermasz bajek, wstęp i posłowie W. Gębik, Warszawa 1957.

${ }^{26}$ Nowy kiermasz bajek, wstęp W. Gębik, Warszawa 1962 (wyd. zm. ukazały się w latach 1965, 1969, 1976, 1978, 1983)

${ }^{27}$ Królowa jezior. Baśnie i legendy Warmii i Mazur, wybór i red. J. J. Rojek, Olsztyn 1988.

${ }^{28}$ Baśnie z krainy tysiąca jezior, wybór i red. J. J. Rojek, Olsztyn 1989.

${ }^{29}$ T. Brzeska-Smerek, Literatura Warmii i Mazur dla dzieci i młodzieży. Tradycja i współczesność.

${ }^{30}$ Antologia Warmińska. Warmia w baśniach, podaniach i legendach, wybór, oprac. i wstęp T. Brzeska-Smerek, Olsztyn 2011.

${ }^{31}$ Zob. http://aw.mbp.olsztyn.pl/do-czytania.html (dostęp: 16.04.2020)

32 Jak czytamy na s. 2: „Antologia Warmińska powstała pod hasłem »kreacja i promo cja nowej marki regionu«”. Projekt został „dofinansowany ze środków Europejskiego Funduszu Rozwoju Regionalnego w ramach Regionalnego Programu Operacyjnego Warmia i Mazury 2007-2013. Warmia i Mazury regionem zjednoczonej Europy".

${ }^{33} \mathrm{H}$. Skrobiszewska, Książki naszych dzieci, czyli o literaturze dla dzieci i młodzieży, Warszawa 1971, s. 146-147.

${ }^{34}$ O księżniczce Warmii i jej bracie Mazurze. Z Waldemarem Mierzwą rozmawia Anita Romulewicz, „Bibliotekarz Warmińsko-Mazurski” 2019, nr 1-2, s. 5. Wywiad z tym wydawca, specjalizującym się w zróżnicowanych tematycznie publikacjach o Mazurach, jest opowieścią o edytorskich intencjach i realizacjach pomysłów związanych z Bajkami mazurskimi.

${ }^{35}$ Nowe, uzupełnione, rozszerzone wydanie książeczki opublikowano w 2013, a następnie w 2016 roku.

${ }^{36}$ Sotomską do badań nad bajkami mazurskimi, szczególnie pochodzącymi z ziemi działdowskiej, zainspirował Skurpski; E. Cherkowska, Z mazurskiego brulionu: Hieronim Skurpski - Honorowy Obywatel Miasta Działdowa, https://www.dzialdowo.pl/dzialdowo-historycznie/z-mazurskiego-brulionu-hieronim-skurpski-honorowy-obywatel-miasta-dzialdowa/ (dostęp: 15.04.2020). Zob. też: E. Sotomska, O „naszych” bajkach, „Bibliotekarz Warmińsko-Mazurski" 2008, nr 3-4, http://www.wbp.olsztyn.pl/bwm/3-4 08-ie/o bajkach.htm (dostęp: 16.04.2020)

Sztuka Edycji 2/2020
2016, s. IX.

Kierz róży. Bajki mazurskie z Działdowszczyzny, oprac. E. Sotomska, Dąbrówno

${ }^{38}$ Zwierzyniec mazurski. Bajki, wybrał, oprac. i wstępem opatrzył Z. Chojnowski Dąbrówno 2016. W serii „Miniatury Mazurskie” tomik nosi nr 8. W podobny sposób wydałem ludowy tekst pt. Wesele ptasząt. Piosenka mazurska (Olsztyn 2013; zob. il. 6). Książecz kę, która jest wyrazem hołdu dla Józefa Wilkonia z okazji jego osiemdziesięciolecia, on właśnie zilustrował.

${ }^{39}$ Jako ciekawostkę podaje, że pod podobnym tytułem Bajki mazurskie: poezje Jan Nepomucen Gątkowski (1814-1878) wydał w 1841 roku w Wiedniu zbiorek bajek epigramatycznych. Tytuł nie ma związku z Mazurami pruskimi ani z żadnym regionalizmem.

${ }^{40}$ M. P. Toeppen, Wierzenia mazurskie, przeł. E. Piltzówna, językowo oprac. i uwspółcześnił T. Ostojski, wstęp A. Szyfer, W. Ogrodziński, oprac. P. Błażewicz, J. M. Łapo, Dąbrówno 2008 .

${ }^{41}$ Idem, Wierzenia mazurskie z dodatkiem, zawierającym klechdy i baśnie Mazurów,

przeł. E. Piltzówna, Warszawa 1894

${ }^{42}$ E. Wiechert, Baśnie, wybór i przekł. T. Ostojski, Olsztyn 1983.

${ }^{43}$ Z. Chojnowski, Od biografii do recepcji. Ernst Wiechert, Konstanty I. Gałczyński, Zbigniew Herbert na Warmii i Mazurach, Olsztyn 2011, s. 21-104.

${ }^{44}$ Bajki, red. T. Willan, Olsztyn [1985?].

${ }^{45}$ Stowarzyszenie Mazurskie, którego Willan był współzałożycielem i przewodniczącym, już w XXI wieku organizowało co roku z myślą o uczących się niemieckiego dzieciach i młodzieży „Dzień bajek i legend”.

${ }^{46}$ T. Willan, Bogata wdowa, Krzyżacki miecz, Nierozłączni, w: Nowy kiermasz bajek, wyd. 2, Warszawa 1969, s. 218-223.

${ }^{47}$ A. Müsse, Der Kreis Rosenberg: ein westpreussisches Heimatbuch, Halle in Westfalen 1963.

${ }^{48}$ W. Niesiobędzki, Słowo wstępne, w: idem, Księżniczka z Kesselbergu i inne legendy znad Jezioraka, Itawa 2000, s. 5.

${ }^{49}$ Der grosse Schatz masurischer Märchen, Sagen und Legenden. 8 Volksmärchen aus Masuren über Menschen, Dämonen, Götter und andere vergängliche Angelegenheiten geschrieben von Günter Schiwy / Wielki skarbiec mazurskich bajek, legend i podań. 18 ludowych gawęd z mazurskiej krainy o ludziach, demonach, bóstwach oraz innych przemijających sprawach opisanych przez Güntera Schiwy'ego, przeł. D. Serafin, Olsztyn 2007.

${ }^{50}$ G. Schiwy, Posłowie, w: ibidem, s. 129.

${ }^{51}$ Die Frau mit dem Bernsteinhaar. Masurishe Sagen und Märchen / Kobieta o bursztynowych włosach. Mazurskie legendy i baśnie, wg M. Toeppena na nowo opracował H. Somplatzki, przeł. T. Ostojski, rysunki H. Skurpski, wstęp R. Wolski, Olsztyn 1999.

${ }^{52}$ Czarci Ostrów. Wielki zbiór podań ludowych z Mazur, zebrał, przełożył i oprac. J. M. Łapo, Dąbrówno 2014. Książka wyszła w serii „Moja Biblioteka Mazurska” (nr 24). Edycję tę poprzedziło wydanie według tych samych zasad dwóch zbiorów Łapo, W cieniu Zamkowej Góry. Zbiór podań ludowych z Mazur Wschodnich, Dąbrówno 2006 i Tragarz duchów. Zbiór podań ludowych z Mazur, Dąbrówno 2007. W Czarcim Ostrowie dodano siedemdziesiąt dziewieć podań, których nie ma w żadnym z tych wydań.

${ }^{53}$ Jek chłop lab'ńdzia za bziołka wzioł = Jak chłop łabędzia za żonę wziąt, scenariusz M. Wakar, rys. J. Gach, przeł. E. Cyfus, Olsztyn 2006; Ło królu i szurku w czepku łurodzónam = = O królu i chłopcu w czepku urodzonym, scenariusz M. Wakar, rys. J. Gach, przeł. E. Cyfus, Olsztyn 2007; Skónd sia wzióła wyspa Lalka na Łanskam jyziorze = Jak powstała wyspa Lalka na jeziorze Łańskim, scenariusz M. Wakar, rys. J. Gach, przeł. E. Cyfus, Olsztyn 2009.

${ }^{54}$ W tym samym roku ukazała się śląska wersja Mały Princ w przekładzie Grzegorza Kulika. Ale jeszcze w 2015 roku Szatkowski przetłumaczył baśń francuską na język pruski, w którym jej tytuł brzmi: Likuts princis. Ta inicjatywa translatorsko-wydawnicza również wiąże się z działaniami na rzecz upowszechnienia historycznej mowy Prusów.

${ }^{55}$ P. Szatkowski, Mazurski Fébel abo mazurská fibla, czyli elementarz mowy mazurskiej, wstęp Z. Chojnowski, Ełk 2019. 